\title{
Microstructure and Mechanical Properties of Extruded Mg-Zn-Y Alloys with 14H Long Period Ordered Structure
}

\author{
Shintaro Yoshimoto ${ }^{1, *}$, Michiaki Yamasaki ${ }^{2,3}$ and Yoshihito Kawamura ${ }^{2,3}$ \\ ${ }^{1}$ Graduate School of Science and Technology, Kumamoto University, Kurokami, Kumamoto 860-8555, Japan \\ ${ }^{2}$ Department of Materials Science, Kumamoto University, Kurokami, Kumamoto 860-8555, Japan \\ ${ }^{3} 21$ st Century COE Program for "Pulsed Power Science”, Kumamoto University, Kurokami, Kumamoto 860-8555, Japan
}

\begin{abstract}
The compositional dependence of mechanical properties and microstructural change of the extruded $\mathrm{Mg}-\mathrm{Zn}-\mathrm{Y}$ alloys has been investigated in the effort to develop a high strength $\mathrm{Mg}-\mathrm{Zn}-\mathrm{Y}$ alloy with long period ordered (LPO) structure. The extruded alloy $\mathrm{Mg}_{96} \mathrm{Zn}_{2} \mathrm{Y}_{2}$ exhibited a high yield strength of $390 \mathrm{MPa}$ and elongation of $5 \%$ at room temperature, and of more than $300 \mathrm{MPa}$ even at the elevated temperature of $473 \mathrm{~K}$. The heat-treated ingot metallurgy $(\mathrm{I} / \mathrm{M}) \mathrm{Mg}-\mathrm{Zn}-\mathrm{Y}$ alloys containing very small amounts of yttrium and zinc are characterized by a lamellar phase constructed of $2 \mathrm{H}-\mathrm{Mg}$ and $14 \mathrm{H}-\mathrm{LPO}$ structures. Extrusion of the Mg-Zn-Y I/M alloys with LPO structure led to refinement of $\alpha$ - Mg grains and high dispersion of a hard lamellar phase consisting of torn-off $2 \mathrm{H}-\mathrm{Mg}$ and bent LPO structures with random grain boundaries, resulting in strengthening of the alloys.
\end{abstract}

(Received October 12, 2005; Accepted January 17, 2006; Published April 15, 2006)

Keywords: magnesium, magnesium-zinc-yttrium, long period ordered (LPO) structure, extrusion, mechanical properties

\section{Introduction}

From an environmental point of view, magnesium alloys are very attractive materials because of their light weight and ease of recycling. Several wrought magnesium alloys such as AM50 and AZ31 have seen increasing use in automotive and industrial applications. ${ }^{1,2)}$ However, the above mentioned commercial alloys have sub-optimal mechanical properties, including strength. Recently, Kawamura et al. have developed a rapidly solidified powder metallurgy (RS P/M) $\mathrm{Mg}_{97} \mathrm{Zn}_{1} \mathrm{Y}_{2}($ at $\%)$ alloy with excellent mechanical properties including a tensile yield strength of $610 \mathrm{MPa}$ and elongation of $5 \%$ at room temperature. ${ }^{3)}$ Moreover, the alloy exhibited high corrosion resistance ${ }^{4)}$ and high-strain-rate superplasticity, and its elongation reached about $700 \%$ at $623 \mathrm{~K}$. The alloy consists of fine grains of $\alpha-\mathrm{Mg}$ ranging in size from 100 to $200 \mathrm{~nm}$, and a novel 18R-type long period ordered (LPO) structure ${ }^{5-9)}$ The superior mechanical properties of this alloy seem to originate both in the fine-grained $\alpha$-Mg matrix and the LPO structure. Itoi et al. reported that 18R and 14H-type LPO structures were formed not only in rapidly solidified alloy but in as-cast Mg-Zn-Y alloys. Furthermore, 18R-type LPO structure transformed to 14H-type LPO structure by heat-treatment at $773 \mathrm{~K}$. It was also found that the hardness of the secondary phase with the LPO structure is greater than that of the $2 \mathrm{H}-\mathrm{Mg}$ matrix grains. ${ }^{10)}$ The appearance of the LPO structure may be expected to improve the mechanical properties of $\mathrm{Mg}_{97} \mathrm{Zn}_{1} \mathrm{Y}_{2}$ alloys. However, the as-cast $\mathrm{Mg}_{97} \mathrm{Zn}_{1} \mathrm{Y}_{2}$ alloys exhibit low tensile strength because of coarse grains in their microstructure. ${ }^{11)}$ In order to bring out the advantages of the LPO structure, it is necessary to control the microstructure of the alloys by using rapid solidification, ${ }^{3,9,12)}$ extrusion, ${ }^{13)}$ and so on. Extrusion ${ }^{14,15)}$ and rolling ${ }^{16,17)}$ processes, in particular, have been widely used for grain refinement in the microstructure of $\mathrm{Mg}$ alloys.

In this study, we have performed the hot-extrusion of cast

*Graduate Student, Kumamoto University
$\mathrm{Mg}-\mathrm{Zn}-\mathrm{Y}$ alloys heat-treated at $773 \mathrm{~K}$ with a $14 \mathrm{H}-\mathrm{LPO}$ structure, so as to obtain fine microstructure. Particular attention has been paid to the changes in structure, and $14 \mathrm{H}-$ LPO structure dispersion, of the $\mathrm{Mg}-\mathrm{Zn}-\mathrm{Y}$ alloys before and after the extrusion of alloys of different compositions, in order to clarify the compositional dependence of their mechanical properties, that is, tensile strength and elongation.

\section{Experimental Procedure}

The alloy compositions used in this study were $\mathrm{Mg}_{100-x-y} \mathrm{Zn}_{x} \mathrm{Y}_{y}$ (at\%, $\left.x=0-2.5, y=0-3\right)$. Their ingots were prepared by high-frequency induction melting in an $\mathrm{Ar}$ atmosphere followed by homogenizing at $773 \mathrm{~K}$ for $10 \mathrm{~h}$. The cast ingots were cut into rods with a diameter of $29 \mathrm{~mm}$ and length of $70 \mathrm{~mm}$. The rods were extruded with an extrusion ratio of 10 , at $623 \mathrm{~K}$ and a ram speed of $2.5 \mathrm{~mm} \cdot \mathrm{s}^{-1}$. The structure of the alloys before and after extrusion was investigated by X-ray diffractometry (XRD), scanning electron microscopy (SEM) and transmission electron microscopy (TEM). All samples were cut transverse to the direction of extrusion. Tensile tests were carried out using an Instron-type tensile testing machine at room and elevated temperatures with an initial strain rate of $5 \times 10^{-4} \mathrm{~s}^{-1}$. The dimensions of tensile specimens were $2.5 \mathrm{~mm}$ in diameter and $15 \mathrm{~mm}$ long for room-temperature tests, and $1.5 \mathrm{~mm}$ diameter and $10 \mathrm{~mm}$ long for elevated-temperature tests. The tensile axis was along the direction of extrusion.

\section{Results}

\subsection{Mechanical properties}

Figure 1(a) shows the variation in the tensile strength and elongation of extruded $\mathrm{Mg}_{99-x} \mathrm{Zn}_{1} \mathrm{Y}_{x}$ alloy as function of yttrium content. The yield strength of the alloy increased considerably up to $320 \mathrm{MPa}$ with the addition of $0.5 \mathrm{at} \%$ yttrium to the $\mathrm{Mg}_{99} \mathrm{Zn}_{1}$ binary alloy, which had a low 


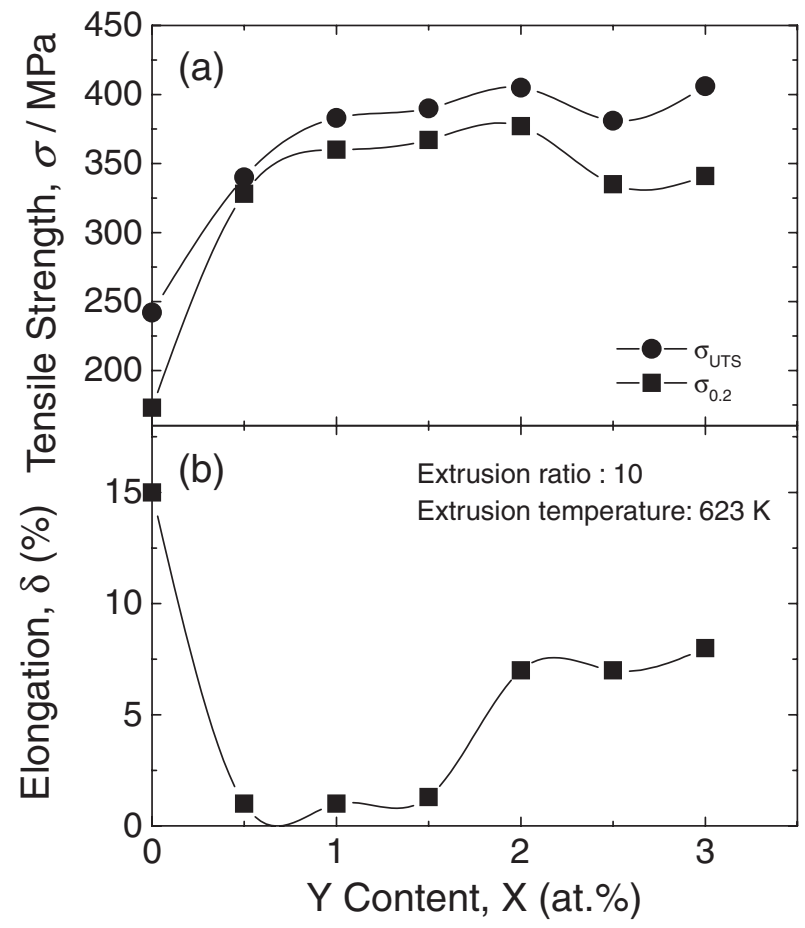

Fig. 1 Yttrium content dependence of (a) the tensile strength and (b) elongation at room temperature for $\mathrm{Mg}_{99-x} \mathrm{Zn}_{1} \mathrm{Y}_{x}$ alloys extruded at $623 \mathrm{~K}$.

strength of only $170 \mathrm{MPa}$. Furthermore, the yield strength of the alloy gradually increased with increasing yttrium content from 0.5 to 2.0 at $\%$ but it reached a peak yield strength of $377 \mathrm{MPa}$ at $2.0 \mathrm{at} \%$ yttrium, and thereafter the yield strength decreased. The elongation of the $\mathrm{Mg}_{99-x} \mathrm{Zn}_{1} \mathrm{Y}_{x}$ alloys decreased considerably when below $1 \%$ in the range of $0.5-1.5$ at\% added yttrium, although the $\mathrm{Mg}_{99} \mathrm{Zn}_{1}$ binary extruded alloy exhibited elongation of $15 \%$. However, more than 2.0 at $\%$ yttrium added to $\mathrm{Mg}_{99-x} \mathrm{Zn}_{1} \mathrm{Y}_{x}$ alloy restored the elongation from $1 \%$ to more than $6 \%$. The extruded $\mathrm{Mg}_{97} \mathrm{Zn}_{1} \mathrm{Y}_{2}$ alloy exhibited a yield strength of $377 \mathrm{MPa}$ and elongation of $6 \%$, while the tensile yield strength of the extruded alloy was three times that of the cast counterpart alloy with yield strength of $120 \mathrm{MPa}$.

Figure 2(a) shows the variation in the tensile yield strength and ultimate tensile strength of extruded $\mathrm{Mg}_{98-x} \mathrm{Zn}_{x} \mathrm{Y}_{2}$ alloys as function of zinc content. Addition of more than 1 at $\%$ zinc to $\mathrm{Mg}_{98} \mathrm{Y}_{2}$ binary alloy brings out a high yield strength of greater than $350 \mathrm{MPa}$. Notably, the extruded $\mathrm{Mg}_{96} \mathrm{Zn}_{2} \mathrm{Y}_{2}$ alloy exhibited an excellent yield strength of $390 \mathrm{MPa}$. Figure 2(b) shows the relationship between the zinc content and the elongation of the extruded $\mathrm{Mg}_{98-x} \mathrm{Zn}_{x} \mathrm{Y}_{2}$ alloy. The elongation gradually decreased with increasing zinc content, except for $\mathrm{Mg}_{96.5} \mathrm{Zn}_{1.5} \mathrm{Y}_{2}$ extruded alloy having below $1 \%$ elongation. Therefore, it was found that the $\mathrm{Mg}_{96} \mathrm{Zn}_{2} \mathrm{Y}_{2}$ extruded alloy exhibited the good combination of a high strength of $390 \mathrm{MPa}$ and an elongation of $5 \%$.

Figure 3 shows the mechanical properties of the extruded $\mathrm{Mg}_{97} \mathrm{Zn}_{1} \mathrm{Y}_{2}$ and $\mathrm{Mg}_{96} \mathrm{Zn}_{2} \mathrm{Y}_{2}$ alloys, and commercial heatresistant WE54A-T6 magnesium alloy at elevated temperature. ${ }^{18)}$ It is noteworthy that these extruded $\mathrm{Mg}-\mathrm{Zn}-\mathrm{Y}$ alloys had very high strength, with the yield strength greater than

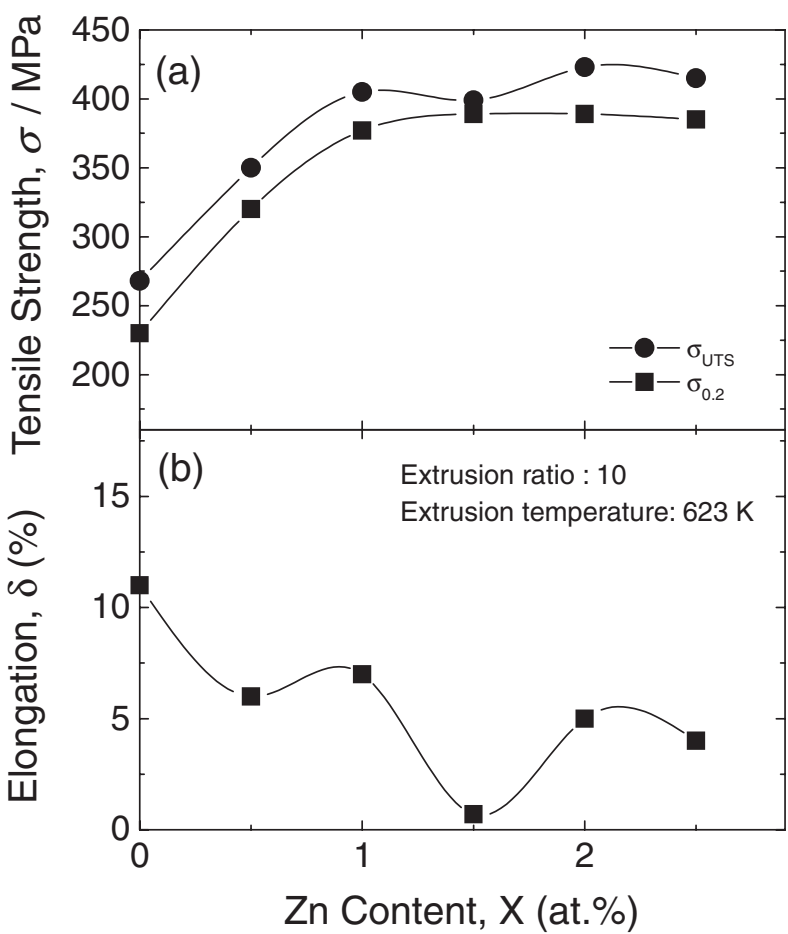

Fig. 2 Zinc content dependence of (a) the tensile strength and (b) elongation at room temperature for $\mathrm{Mg}_{98-x} \mathrm{Zn}_{x} \mathrm{Y}_{2}$ alloys extruded at $623 \mathrm{~K}$.

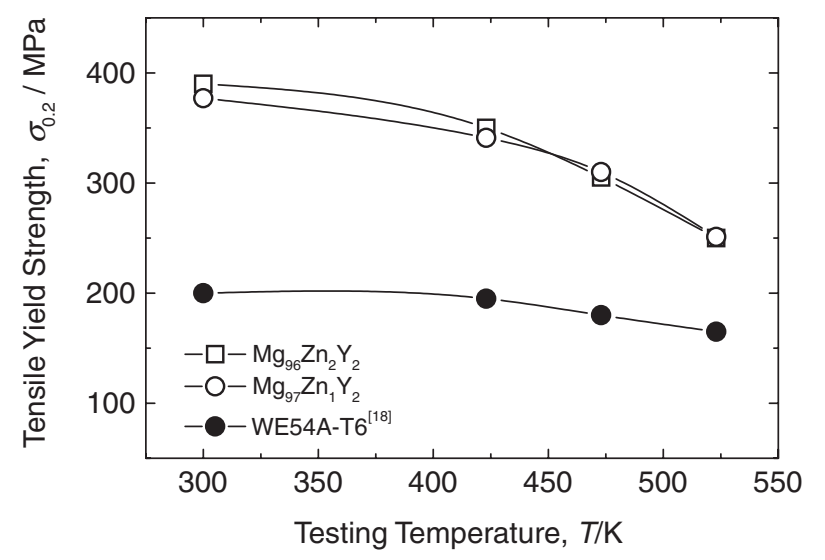

Fig. 3 Tensile yield strength of extruded $\mathrm{Mg}_{97} \mathrm{Zn}_{1} \mathrm{Y}_{2}, \mathrm{Mg}_{96} \mathrm{Zn}_{2} \mathrm{Y}_{2}$ alloys and commercial I/M WE54-T6 alloy at elevated temperatures.

$300 \mathrm{MPa}$ even at $473 \mathrm{~K}$, where their yield strength was about 1.5 times that of the commercial alloy WE54-T6. The extruded $\mathrm{Mg}_{97} \mathrm{Zn}_{1} \mathrm{Y}_{2}$ and $\mathrm{Mg}_{96} \mathrm{Zn}_{2} \mathrm{Y}_{2}$ alloys are promising materials for practical use because of their mechanical properties at room and elevated temperatures.

\subsection{Microstructures}

Figure 4 shows XRD patterns of the extruded $\mathrm{Mg}_{97} \mathrm{Zn}_{1} \mathrm{Y}_{2}$, $\mathrm{Mg}_{96.5} \mathrm{Zn}_{1.5} \mathrm{Y}_{2}$, and $\mathrm{Mg}_{96} \mathrm{Zn}_{2} \mathrm{Y}_{2}$ alloys. The $\mathrm{Mg}_{97} \mathrm{Zn}_{1} \mathrm{Y}_{2}$ and $\mathrm{Mg}_{96.5} \mathrm{Zn}_{1.5} \mathrm{Y}_{2}$ alloys consisted of two phases of $\alpha-\mathrm{Mg}$ and $\mathrm{Mg}_{12} \mathrm{ZnY}$ corresponding to an LPO structure. ${ }^{7,19)}$ In contrast, $\mathrm{Mg}_{96} \mathrm{Zn}_{2} \mathrm{Y}_{2}$ was composed of three phases: $\alpha-\mathrm{Mg}, \mathrm{Mg}_{12} \mathrm{ZnY}$, and $\mathrm{Mg}_{3} \mathrm{Zn}_{3} \mathrm{Y}_{2}$ compounds. Addition of more than 2 at\% zinc to $\mathrm{Mg}_{98-x} \mathrm{Zn}_{x} \mathrm{Y}_{2}$ alloy resulted in the formation of $\mathrm{Mg}_{3} \mathrm{Zn}_{3} \mathrm{Y}_{2}$ compounds. There was no structural difference before and 


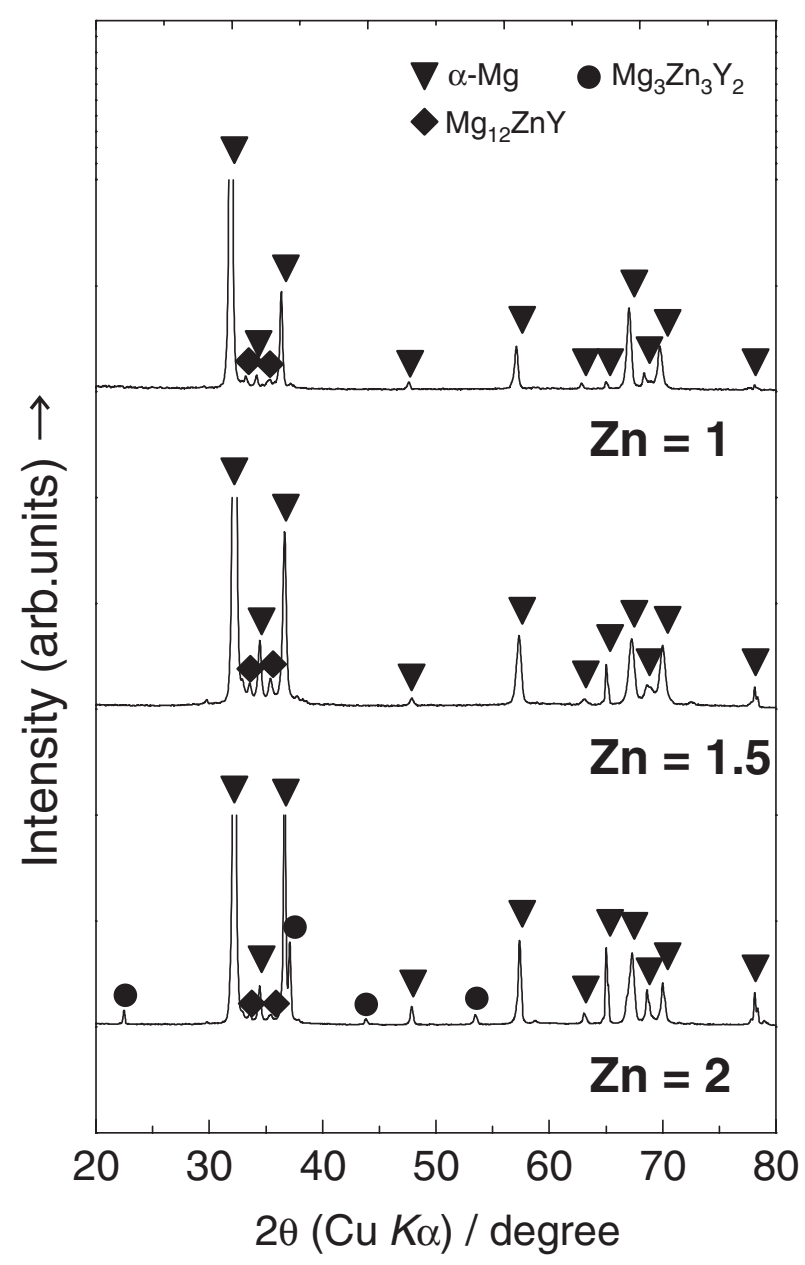

Fig. 4 XRD patterns of $\mathrm{Mg}_{97} \mathrm{Zn}_{1} \mathrm{Y}_{2}, \mathrm{Mg}_{96.5} \mathrm{Zn}_{1.5} \mathrm{Y}_{2}$, and $\mathrm{Mg}_{96} \mathrm{Zn}_{2} \mathrm{Y}_{2}$ alloys extruded at $623 \mathrm{~K}$.

after extrusion, though XRD patterns of heat-treated alloys before extrusion were not included in Fig. 4. In addition, these XRD patterns show that the extruded alloys have a remarkable orientation, as seen from three major peaks

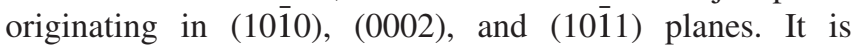
considered that the basal plane is parallel to the direction of extrusion. $^{20)}$

Figure 5 shows SEM images of homogenized and extruded $\mathrm{Mg}_{98-x} \mathrm{Zn}_{x} \mathrm{Y}_{2}$ alloys. The secondary phase, with fine lamellar contrasts, was observed in all samples examined in this study. As noted with XRD, these alloys consisted of $\alpha$ $\mathrm{Mg}$ and $\mathrm{Mg}_{12} \mathrm{ZnY}$ phases. Therefore, the fine-lamellar contrast of the secondary phase is considered to be due to an LPO structure. ${ }^{5-8,10)}$ In $\mathrm{Mg}_{97} \mathrm{Zn}_{1} \mathrm{Y}_{2}$ alloy, the refinement of microstructure and dispersion of the lamellar phase were observed after extrusion as shown in Figs. 5(a) and (b). Figures 5(a) and (c) show that the volume fraction of lamellar phase increased with increasing zinc content, but a maximum volume fraction of lamellar phase was exhibited in the $\mathrm{Mg}_{96.5} \mathrm{Zn}_{1.5} \mathrm{Y}_{2}$ alloy. In the $\mathrm{Mg}_{96.5} \mathrm{Zn}_{1.5} \mathrm{Y}_{2}$ alloy, the refinement of microstructure did not seem to occur during extrusion because of the deformation resistance of the LPO structure. However, addition of more than 2 at $\%$ zinc to $\mathrm{Mg}_{98-x} \mathrm{Zn}_{x} \mathrm{Y}_{2}$ alloy caused a reduction in the amount of lamellar phase due to formation of $\mathrm{Mg}_{3} \mathrm{Zn}_{3} \mathrm{Y}_{2}$ compound.
The refinement of microstructure, including high dispersion of the lamellar phase and $\mathrm{Mg}_{3} \mathrm{Zn}_{3} \mathrm{Y}_{2}$ compound in the $\mathrm{Mg}_{96} \mathrm{Zn}_{2} \mathrm{Y}_{2}$ alloy was confirmed as well as in $\mathrm{Mg}_{97} \mathrm{Zn}_{1} \mathrm{Y}_{2}$ alloy.

Figure 6 shows TEM images of the extruded $\mathrm{Mg}_{97} \mathrm{Zn}_{1} \mathrm{Y}_{2}$ and $\mathrm{Mg}_{96.5} \mathrm{Zn}_{1.5} \mathrm{Y}_{2}$ alloys viewed under low magnification. The extruded $\mathrm{Mg}_{97} \mathrm{Zn}_{1} \mathrm{Y}_{2}$ alloy has fine $\alpha-\mathrm{Mg}$ grains with a small amount of the LPO structure (Fig. 6(a)). The grain size of $\alpha-\mathrm{Mg}$ was reduced to approximately $1 \mu \mathrm{m}$ during extrusion. On the other hand, the extruded $\mathrm{Mg}_{96.5} \mathrm{Zn}_{1.5} \mathrm{Y}_{2}$ alloy has two types of microstructure. One is typified by fine $\alpha$-Mg matrix grains with a small amount of the LPO structure (Fig. 6(b)) as in the extruded $\mathrm{Mg}_{97} \mathrm{Zn}_{1} \mathrm{Y}_{2}$ and $\mathrm{Mg}_{96} \mathrm{Zn}_{2} \mathrm{Y}_{2}$ alloys. The other is coarse grains with a large amount of the LPO structure (Fig. 6(c)). The large block-like LPO structure renders lamellar phase dispersion and grain refinement insufficient during extrusion.

Figure 7 shows the TEM images and diffraction patterns of the extruded $\mathrm{Mg}_{96} \mathrm{Zn}_{2} \mathrm{Y}_{2}$, obtained through homogenized at $773 \mathrm{~K}$ for $10 \mathrm{~h}$ before extrusion. The selected area electron diffraction patterns taken from area $\mathrm{A}$ and $\mathrm{B}$ indicate $\mathrm{Mg}_{3} \mathrm{Zn}_{3} \mathrm{Y}_{2}$ (cubic with $\mathrm{a}=0.68 \mathrm{~nm}$ ) and $14 \mathrm{H}$-type LPO structure, ${ }^{10,13)}$ respectively. The extrusion process brings about moderate and continuous bending of the LPO structure with any given angle and refinement of $\alpha-\mathrm{Mg}$ and $\mathrm{Mg}_{3} \mathrm{Zn}_{3} \mathrm{Y}_{2}$ compound. The cracked $\mathrm{Mg}_{3} \mathrm{Zn}_{3} \mathrm{Y}_{2}$ compound was often observed next to bent LPO structure (Fig. 7(a)). A lowmagnification HRTEM image of the bent LPO structure shows a random grain boundary rather than a twin boundary (Fig. 7(b)). These results suggest that the deformation is different in the $2 \mathrm{H}-\mathrm{Mg}$ structure and the LPO structure and that ductility of LPO phase is higher than that of $\mathrm{Mg}_{3} \mathrm{Zn}_{3} \mathrm{Y}_{2}$ compound. The high strength and ductility seems to originate in the bent LPO structure as well as the refinement of microstructure.

\section{Discussion}

This study has shown that the strengthening of certain extruded $\mathrm{Mg}-\mathrm{Zn}-\mathrm{Y}$ alloys is due to their highly dispersed LPO structure and fine-grained $\alpha-\mathrm{Mg}$ matrix grains. Therefore, effective control of the microstructure including the dispersion of the fine-lamellar structure (the 14H-LPO and $2 \mathrm{H}-\mathrm{Mg}$ structure) seems to be important for further enhancement of the mechanical properties of $\mathrm{Mg}-\mathrm{Zn}-\mathrm{Y}$ alloys. In order to provide useful information on the relationship between microstructure and the mechanical properties of extruded $\mathrm{Mg}-\mathrm{Zn}-\mathrm{Y}$ alloys, we will discuss the effects of alloy compositional control on the formation of LPO structure and of warm extrusion on its dispersion.

The addition of a very small amount of zinc and yttrium to magnesium brings about the formation of an LPO structure in cast $\mathrm{Mg}-\mathrm{Zn}-\mathrm{Y}$ alloys. In the $\mathrm{Mg}_{98-x} \mathrm{Zn}_{x} \mathrm{Y}_{2}$ alloys, the volume fraction of the lamellar phase, including the LPO structure, increases with increasing zinc content. However, the addition of more than 2 at\% zinc to $\mathrm{Mg}_{98-x} \mathrm{Zn}_{x} \mathrm{Y}_{2}$ alloy causes the formation of the $\mathrm{Mg}_{3} \mathrm{Zn}_{3} \mathrm{Y}_{2}$ compound adjacent to the LPO structure in homogenized alloys. The appearance of these phases, that is, LPO structure and $\mathrm{Mg}_{3} \mathrm{Zn}_{3} \mathrm{Y}_{2}$ compound, can be controlled in homogenization by adjusting the alloy 

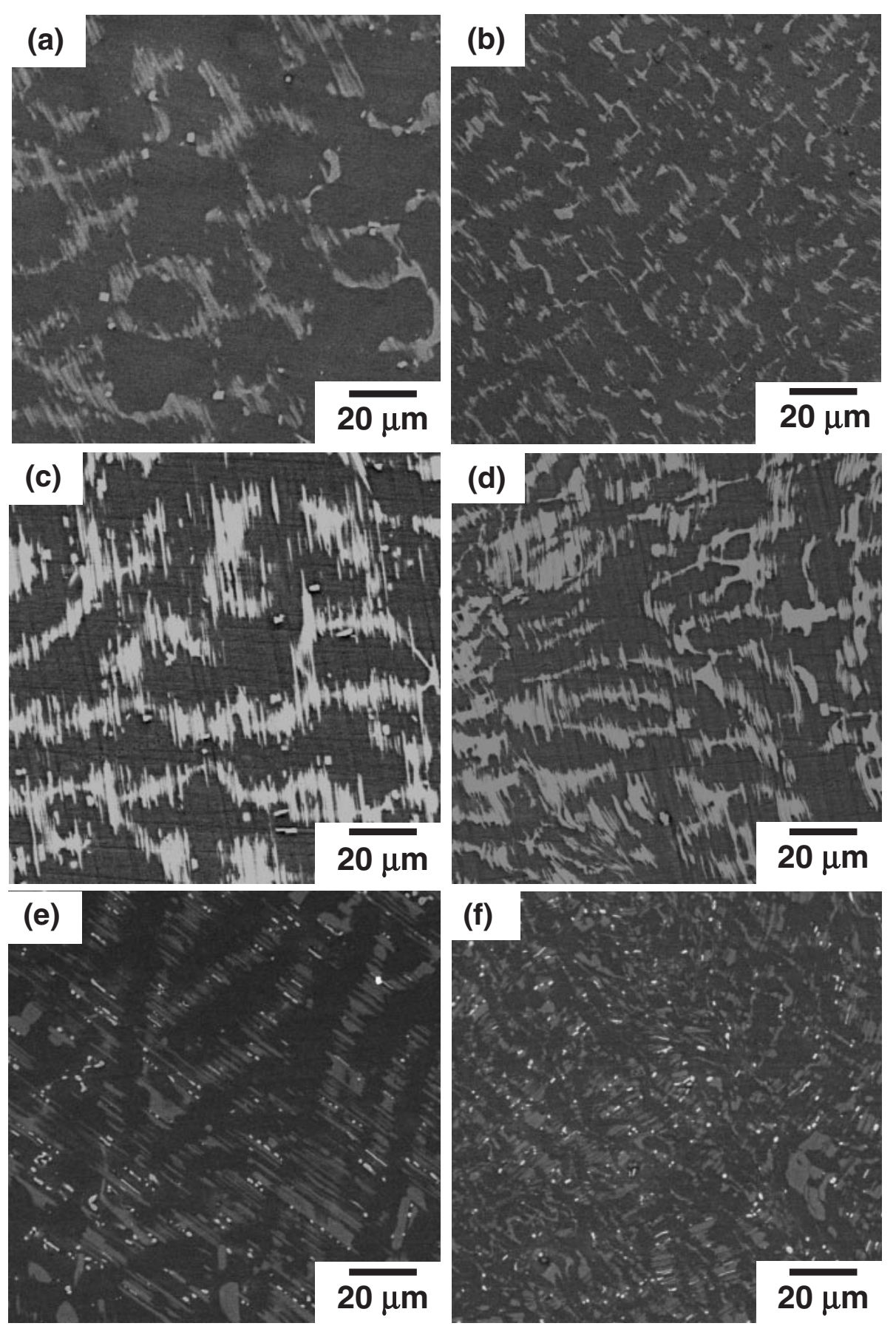

Fig. 5 SEM images of the homogenized and the extruded $\mathrm{Mg}_{98-x} \mathrm{Zn}_{x} \mathrm{Y}_{2}$ alloys. (a) Homogenized and (b) extruded $\mathrm{Mg}_{97} \mathrm{Zn}_{1} \mathrm{Y}_{2}$ alloys, (c) homogenized and (d) extruded $\mathrm{Mg}_{96.5} \mathrm{Zn}_{1.5} \mathrm{Y}_{2}$ alloys, (e) homogenized and (f) extruded $\mathrm{Mg}_{96} \mathrm{Zn}_{2} \mathrm{Y}_{2}$ alloys.

composition. It is known that the lamellar phase, including the $\mathrm{LPO}$ and $2 \mathrm{H}-\mathrm{Mg}$ structures, is harder than the $\alpha-\mathrm{Mg}$ grains. ${ }^{10)}$ However, the as-cast $\mathrm{Mg}_{97} \mathrm{Zn}_{1} \mathrm{Y}_{2}$ alloy has a low tensile strength of only $120 \mathrm{MPa}$ because of the coarse $\alpha-\mathrm{Mg}$ grain size and localized and large-sized lamellar phases near grain boundaries as shown in Fig. 5.

Warm extrusion is an effective technique to improve the mechanical properties of $\mathrm{Mg}-\mathrm{Zn}$-rare earth element alloys with lamellar phases, acting to refine the $\alpha-\mathrm{Mg}$ matrix grains and to disperse the lamellar phase. ${ }^{13)}$ From XRD results before and after extrusion, it is clear that neither phase change nor decomposition occurred in $\mathrm{Mg}-\mathrm{Zn}-\mathrm{Y}$ alloys. However, as SEM and TEM show in Figs. 5 and 6, the refinement of $\alpha-\mathrm{Mg}$ grains, the high dispersion of lamellar phases, and the bending of the LPO structure with any given angle were certainly observed. Furthermore, the low-magnification HRTEM image reveals that the bent LPO has many random grain boundaries, i.e. a bent LPO structure is an aggregate of fine-grained LPO structures. The improvement of mechanical properties in these extruded $\mathrm{Mg}-\mathrm{Zn}-\mathrm{Y}$ alloys is considered to originate in the high dispersion of the bent LPO structure and the refinement of those structures and $\alpha-\mathrm{Mg}$ grains. The tensile yield strength of the extruded $\mathrm{Mg}_{97} \mathrm{Zn}_{1} \mathrm{Y}_{2}$ alloy is three times that of the cast counterpart alloy.

The changes in the elongation of the extruded $\mathrm{Mg}-\mathrm{Zn}-\mathrm{Y}$ alloys are sensitive to microstructure, especially the volume 

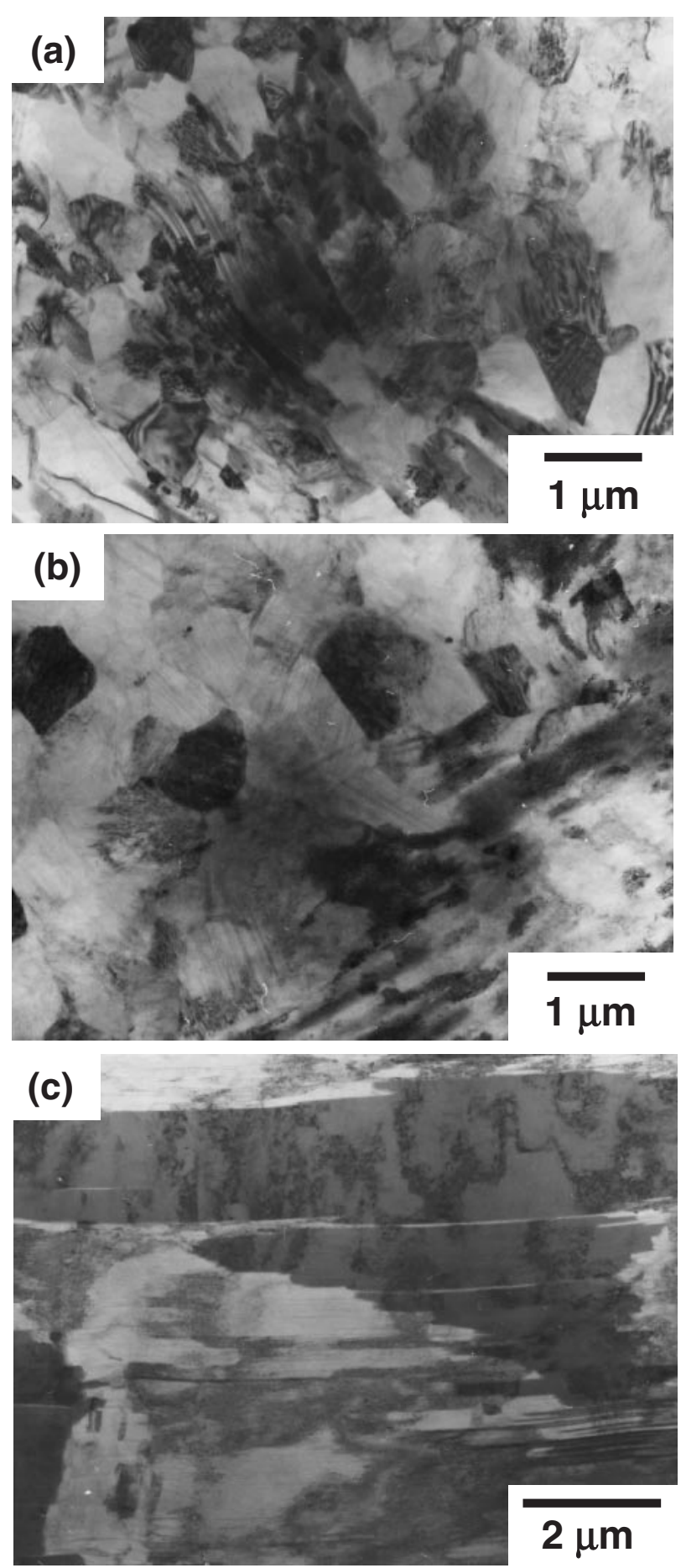

Fig. 6 Low magnification TEM images of the extruded (a) $\mathrm{Mg}_{97} \mathrm{Zn}_{1} \mathrm{Y}_{2}$ and (b, c) $\mathrm{Mg}_{96.5} \mathrm{Zn}_{1.5} \mathrm{Y}_{2}$ alloys, obtained through homogenized at $773 \mathrm{~K}$ for $10 \mathrm{~h}$ before extrusion.

fraction of lamellar phase. In the extruded $\mathrm{Mg}_{98-x} \mathrm{Zn}_{x} \mathrm{Y}_{2}$ alloys, the elongation gradually decreases with increasing zinc content from 0 to 1.0 at $\%$, and declines steeply thereafter to less than $1 \%$ at a zinc content of 1.5 at $\%$. As mentioned above, the volume fraction of lamellar phase increased with increasing zinc content in the range of 0 to 1.5 at $\%$. Excessive formation of the lamellar phase in the Mg-Zn-Y alloys would exert an inhibitory effect on the dispersion of lamellar phase during extrusion because of its high deformation resistance. The elongation of the $\mathrm{Mg}_{98-x} \mathrm{Zn}_{x} \mathrm{Y}_{2}$ alloys containing more than 2 at $\%$ zinc increase up to $5 \%$. The recovery of elongation, in this case, seems to be due to the decreasing volume fraction of lamellar phase as more $\mathrm{Mg}_{3} \mathrm{Zn}_{3} \mathrm{Y}_{2}$ compound is formed. It is natural to assume that the elongation is influenced by the volume fraction of harder intermetallic compound-like phases, that is, $\mathrm{Mg}_{12} \mathrm{ZnY}$ phase corresponding to LPO structure and $\mathrm{Mg}_{3} \mathrm{Zn}_{3} \mathrm{Y}_{2}$ phase. The stoichiometries of $\mathrm{Mg} /(\mathrm{Zn}, \mathrm{Y})$ in the compounds $\mathrm{Mg}_{12} \mathrm{ZnY}$ (LPO) and $\mathrm{Mg}_{3} \mathrm{Zn}_{3} \mathrm{Y}_{2}$ are 6 and 0.6 , respectively. The formation of the LPO structure by the addition of a very small amount of zinc and yttrium results from the much higher proportion of $\mathrm{Mg} /(\mathrm{Zn}, \mathrm{Y})$ in $\mathrm{Mg}_{12} \mathrm{ZnY}$. Furthermore, the excessive added solute elements will be consumed to form the $\mathrm{Mg}_{3} \mathrm{Zn}_{3} \mathrm{Y}_{2}$ compound with the small atomic ratio of $\mathrm{Mg}$ / $(\mathrm{Zn}, \mathrm{Y})$, resulting in suppression of excessive formation of the LPO structure. Alloy composition control is necessary to obtain an appropriate volume fraction of the lamellar phase because a large amount of the LPO structure in cast Mg-Zn-Y renders lamellar phase dispersion and grain refinement insufficient during extrusion, resulting in poor ductility of the extruded alloys (Fig. 6(c)). Furthermore, warm extrusion is effective in refinement of $\alpha-\mathrm{Mg}$ grains and high dispersion of the lamellar phase, that is, the aggregate of the fine-grained LPO structures.

\section{Conclusions}

We have examined the mechanical properties and microstructure of extruded $\mathrm{Mg}-\mathrm{Zn}-\mathrm{Y}$ alloys of varying composition. The results are summarized as follows:

(1) The cast $\mathrm{Mg}-\mathrm{Zn}-\mathrm{Y}$ alloy homogenized at $773 \mathrm{~K}$ consists of the $2 \mathrm{H}-\mathrm{Mg}$ phase and the lamellar phase including $2 \mathrm{H}-\mathrm{Mg}$ and $14 \mathrm{H}$-type LPO structures. The $14 \mathrm{H}$-type LPO structure observed in this study is a thermal equilibrium structure, and its volume fraction can be controlled by varying the zinc and yttrium content of the $\mathrm{Mg}-\mathrm{Zn}-\mathrm{Y}$ ternary alloys.

(2) The extruded $\operatorname{Mg}_{97} \mathrm{Zn}_{1} \mathrm{Y}_{2}, \mathrm{Mg}_{96.5} \mathrm{Zn}_{1.5} \mathrm{Y}_{2}$ and $\mathrm{Mg}_{96} \mathrm{Zn}_{2} \mathrm{Y}_{2}$ alloys have high strength, while the extruded $\mathrm{Mg}_{96.5} \mathrm{Zn}_{1.5} \mathrm{Y}_{2}$ alloy shows poor ductility. The extruded $\mathrm{Mg}_{96.5} \mathrm{Zn}_{1.5} \mathrm{Y}_{2}$ alloy has many coarse grains with a block-like LPO structure, whereas the extruded $\mathrm{Mg}_{97} \mathrm{Zn}_{1} \mathrm{Y}_{2}$ alloy consists of $\alpha-\mathrm{Mg}$ grains with a highly dispersed LPO structure. A large amount of the block-like LPO structure in $\mathrm{Mg}_{96.5} \mathrm{Zn}_{1.5} \mathrm{Y}_{2}$ renders lamellar phase dispersion and grain refinement insufficient during extrusion, resulting in poor ductility of the extruded alloys. The extruded $\mathrm{Mg}_{96} \mathrm{Zn}_{2} \mathrm{Y}_{2}$ alloy consists of three phases: $2 \mathrm{H}-\mathrm{Mg}$ phase, lamellar phase, and $\mathrm{Mg}_{3} \mathrm{Zn}_{3} \mathrm{Y}_{2}$ compound. $\mathrm{Mg}_{3} \mathrm{Zn}_{3} \mathrm{Y}_{2}$ in the $\mathrm{Mg}_{96} \mathrm{Zn}_{2} \mathrm{Y}_{2}$ alloy forms next to the LPO structure, suppressing its excessive formation.

(3) In the Mg-Zn-Y alloys with LPO structure, the extrusion process brings about the refinement of $\alpha-\mathrm{Mg}$ grains and also a high dispersion of the hard lamellar phase consisting of $2 \mathrm{H}-\mathrm{Mg}$ and 14H-type LPO structures. The 14H-type LPO structure can be bent by plastic deformation such as extrusion, with the introduction of random grain boundaries.

(4) Excellent yield strength and elongation were obtained 

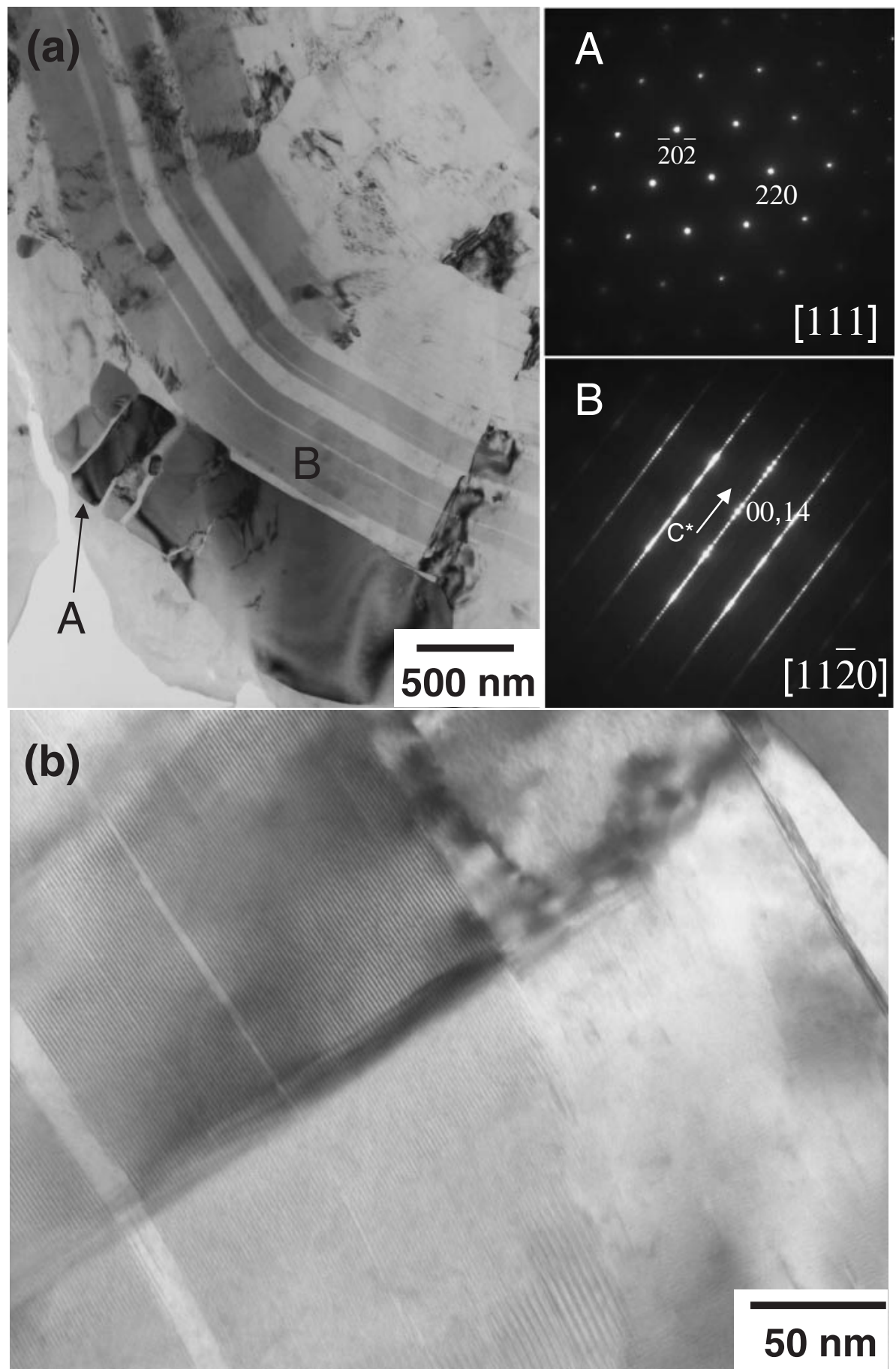

Fig. 7 TEM images and diffraction patterns of the extruded $\mathrm{Mg}_{96} \mathrm{Zn}_{2} \mathrm{Y}_{2}$ alloy, obtained through homogenized at $773 \mathrm{~K}$ for $10 \mathrm{~h}$ before extrusion.

in the extruded $\mathrm{Mg}_{96} \mathrm{Zn}_{2} \mathrm{Y}_{2}$ alloy, with a maximum yield strength of $390 \mathrm{MPa}$ and $5 \%$ elongation at room temperature, and more than $300 \mathrm{MPa}$ of tensile yield strength at the elevated temperature of $473 \mathrm{~K}$.

\section{Acknowledgements}

This work has been financially supported by grant-in-aid for Scientific Research A (No. 16206070) from the Ministry of Education, Science, Sport and Culture, Japan (MEXT). The microstructure observations were partly supported by the "Nanotechnology Support Project (Subject No. 016026,
Institute for Materials Research, Tohoku University)" of MEXT.

\section{REFERENCES}

1) A. A. Luo: Mater. Sci. Forum 419-422 (2003) 57-66.

2) Magnesium \& Magnesium alloys, ed. M. M. Avedesian \& H. Baker: ASM International, Materials Park, OH (1999), 3-6.

3) Y. Kawamura, K. Hayashi and A. Inoue: Mater. Trans., JIM 42 (2001) 1171-1174.

4) M. Yamasaki, K. Nyu and Y. Kawamura: Mater. Sci. Forum 419-422 (2003) 937-942.

5) E. Abe, Y. Kawamura, K. Hayashi and A. Inoue: Acta Mater. 50 (2002) 
3845-3857.

6) D. H. Ping, K. Hono, Y. Kawamura and A. Inoue: Philos. Mag. Lett. 82 (2002) 543-551.

7) Z. P. Luo and S. Q. Zhang: J. Mater. Sci. Lett. 19 (2000) 813-815.

8) Z. P. Luo, S. Q. Zhang, Y. L. Tang and D. S. Zhao: J. Alloys Comp. 209 (1994) 275-278.

9) M. Nishida, Y. Kawamura and T. Yamamuro: Mater. Sci. Eng. A 375377 (2004) 1217-1223.

10) T. Itoi, T. Seimiya, Y. Kawamura and M. Hirohashi: Scr. Mater. 51 (2004) 107-111.

11) Y. Kawamura and S. Yoshimoto: Magnesium Technology 2005, (2005) 499-502.

12) Y. Kawamura, T. Morisaka and M. Yamasaki: Mater. Sci. Forum 419 422 (2003) 751-756.

13) M. Yamasaki, T. Anan, S. Yoshimoto and Y. Kawamura: Scr. Mater.
53 (2005) 799-803.

14) Z. P. Luo, D. Y. Song and S. Q. Zhang: J. Alloys Comp. 230 (1995) $109-114$.

15) A. Singh, M. Nakamura, M. Wantanabe, A. Kato and A. P. Tsai: Scr. Mater. 49 (2003) 417-422.

16) D. H. Bae, S. H. Kim, W. T. Kim and D. H. Kim: Mater. Trans. 42 (2001) 2144

17) D. H. Bae, S. H. Kim, D. H. Kim and W. T. Kim: Acta Mater. 50 (2002) 2343-2356.

18) Magnesium \& Magnesium alloys, ed. M. M. Avedesian \& H. Baker: ASM International, Materials Park, OH (1999), 242-244.

19) Joint Committee on Powder Diffraction Standards, "Powder Diffraction File, Inorganic Phases," Card 36-1273.

20) T. Mukai, M. Yamanoi, H. Watanabe and K. Higashi: Scr. Mater. 45 (2001) 89-94. 